\title{
Do Credit Supply and Unemployment Risk Matter for Household Saving? Evidence from Poland
}

Aneta Maria Kłopocka and Ryszard Wilczyński

\begin{abstract}
This paper contributes to the literature on the effects of uncertainty on household saving - a long-standing and extensively explored topic yet leaving a number of issues inconclusive. It concentrates on the labor income uncertainty by addressing saving against unemployment risk in terms of changes in credit supply and households' financial wealth. Time series analysis uses dataset of quarterly observations from 2003 Q4 to 2019 Q3 for Poland. It provides empirical evidence of the negative relationship of changes in households financial wealth and credit availability with the household propensity to save, in line with the buffer saving model. Furthermore, it contributes to the discussion on the choice of uncertainty measures referring to the labor market with a recommendation to employ the subjective (perceived) unemployment expectation index rather than the objective unemployment rate. These results are meaningful for policy implications. They emphasize the role of credit availability for household consumption/saving decisions. In case of expansionary monetary policy and making credit easier to acquire for households, all other things equal, a negative effect on the household saving rate may be expected. This poses a question about the risk of households' overreliance on credit and therefore about their financial stability in emergency situations.
\end{abstract}

KEY WORDS: $\quad$ Credit, household saving, unemployment risk, uncertainty, Poland.

JEL Classification: E21, E24, G51.

University of Economics and Human Sciences in Warsaw, Poland

\section{Introduction}

The development of household saving is an issue of great interest to forecasters, policymakers, financial markets, and the business community. An impressive body of theoretical and empirical literature elaborates on the determinants of household saving. The core theoretical considerations on consumption and saving include the permanent income hypothesis, the life-cycle hypothesis, and the Ricardian equivalence hypothesis. A significant fraction of the literature addresses the effect of uncertainty on households saving behavior. The precautionary motive (to build up a reserve against unforeseen contingencies) is fundamental for the buffer-stock saving model (Carroll, 1997; Deaton, 1991). According to the

Correspondence concerning this article should be addressed to:

Aneta Maria Kłopocka, University of Economics and Human Sciences in Warsaw, Poland ul. Okopowa 59, 01-043 Warsaw, Poland. E-mail:a.klopocka@vizja.pl model, there is a target level of wealth. Forwardlooking, risk-averse consumers increase their saving when actual wealth, relative to income, is below the optimal target wealth to income. When wealth is above the target level, they increase consumption.

Lugilde et al. (2019) provide a comprehensive review of the empirical literature on precautionary saving. Their main finding is that the empirical results are not conclusive, and that "there is neither consensus on the intensity of that motive for saving, nor on the most appropriate measure of uncertainty" (Lugilde et al., 2019, p. 481). Many empirical studies investigating buffer-stock saving are performed for the United States or other developed economies. Studies of former socialist economies in Central and Eastern Europe (CEE) are sparse.

Our aim in this paper is to provide an empirical evaluation of household saving against unemployment risk in terms of changes in 
credit supply and households' financial wealth in Poland. We test the hypothesis that increases in the financial wealth scaled to income and improvements in the credit availability decrease household saving propensity, while increments in perceived unemployment risk positively affect saving propensity. Furthermore, we contribute to the dispute on the choice of uncertainty measures related to the labor market.

To deliver insights on household saving in Poland - one of the CEE countries with a socialist history - is of great importance. Firstly, household perception of saving motives as well as saving habits may be different in a post-transition and post-communist country than in the developed economies. Moreover, cross-cultural differences may be manifested in diverse patterns of financial decision-making and investment behavior across countries and regions (Czerwonka, 2019; Harasim, 2012). Secondly, the CEE countries have had, at the same time, both relatively low and fluctuating saving rates and also a volatile macroeconomic environment with large fluctuations in growth rates, unemployment and inflation rates (Kukk \& Staehr, 2017). Thirdly, household saving determines, to a considerable extent, the economic outlook of national economies and the financial sustainability of individuals and families (Odoardi \& Pagliari, 2020). Thus, it may contribute to the convergence of Poland towards the more advanced economies in the macro- and microeconomic perspective. In this context, the research on determinants of Polish household saving behavior is particularly appropriate.

The rest of the paper is organized as follows. Section 2 provides a brief review of relevant literature. Section 3 describes the data and the methodology of the research. Section 4 presents and discusses the empirical findings of regression analysis. Section 5 concludes with some remarks.

\section{Literature Review}

Household consumption/saving decisions are central to the functioning of the economy. Household saving is defined as the difference between household disposable income (mainly wages received, revenue of the self-employed, and net property income) and consumption (expenditure on goods and services). In other words, saving represents the part of household disposable income which is not spent for consumption. Household saving rate (household saving divided by disposable income) is a widely used measure of household propensity to save. It refers to the flow of saving in a given period. The process of savings accumulation results in the stock of household wealth. Both theoretical and empirical literature on consumption/saving decisions (including saving motives and factors affecting saving) as well as the allocation of savings across different assets is extensive and emerging (Fereidouni \& Tajaddini, 2017; Gomes et al., 2021; Grigoli et al., 2018; Rybaczewska et al., 2020; Thimme, 2016). The neoclassical view implying rationality and optimality of household decisions is supplemented with a bounded rationality theory according to which consumers faced with complex choices make suboptimal decisions due to cognitive limitations, imperfect information and time constraints (Simon, 1955).

A considerable part of the literature addresses the effect of uncertainty on households saving behavior. This is a long-standing topic in research on household saving (Skinner 1988; Dynan 1993). In the seminal works of Carroll (1997) and Deaton (1991) assets play the role of a buffer-stock, and a consumer saves and dissaves in order to smooth consumption in the face of income uncertainty. The precautionary motive (to build up a reserve against unforeseen contingencies) has assumed an important place in the literature on household saving (e.g., Hubbard et al. 1994; Bertaut \& Haliassos 1997; Carroll \& Samwick 1997; Lusardi 1998; Cagetti 2003; Lee \& Sawada 2007; Gunning 2010; Mishra et al. 2012; Ceritoğlu 2013; Chamon et al. 2013; Deidda 2014; Limosani \& Millemaci 2014; Mastrogiacomo \& Alessie 2014; Aizenman et al. 2015; Fulford 2015; Kłopocka 2018a; Vinokurov et al. 2018).

A fresh interest in precautionary saving has become apparent over the last years in the context of amplified financial, economic, and political uncertainty. Some authors have tested the precaution as a potential explanation of the sharp increment in household saving rates during the Great Recession. For example, the estimates of Mody et al. (2012) for a panel of advanced economies imply that at least two-fifths of the sharp increase in household saving rates between 2007 and 2009 can be attributed to the precautionary 
savings motive. Bouyon (2016) provides an analysis of panel data for 13 European countries of the period 2007-2013. He finds evidence of the strong impact of unemployment rates and housing prices upon household saving rate and thus confirms the prominent role played by the precautionary motive during the financial crisis of 2008-2009. Bande and Riveiro (2013), using Spanish regional data for the period 1980-2007, reveal that part of the increase in saving rates is related to precautionary motive and that increased uncertainty causes greater savings rates.

Carroll et al. (2019) argue that the long stability of the U.S. personal saving rate from the 1960s through the early 1980s, subsequent steady decline from the 1980 s to 2007, and substantial increase in 2008-2011 can all be interpreted using a parsimonious bufferstock model of optimal consumption in the presence of labour income uncertainty and credit constraints. Their model's key insight is that, in the presence of income uncertainty, optimizing households have a target wealth ratio that depends on the usual theoretical considerations (risk aversion, time preference, expected income growth, etc.) as well as the degree of labour income uncertainty and the availability of credit. Their model's estimated coefficients imply that a substantial contribution to the decline in consumption during the Great Recession was due to the increase in precautionary saving. The perceived labor income risk is measured by the households' unemployment expectations using the Thomson Reuters/ University of Michigan's Surveys of Consumers. The households' unemployment expectations are assumed to be a better proxy of labor income risk than the unemployment rate.

Broadway and Haisken-DeNew (2019), using household-level panel data, distinguish between real income uncertainty the household is actually exposed to, and perceived income uncertainty. They find that the latter substantially increases precautionary savings beyond the effect of real income uncertainty.

Carroll (1992) and Carroll et al. (2012) show the dynamics of the saving rate adjustment to a permanent increase in uncertainty. In response to a permanent worsening in economic circumstances, consumption initially overshoots its ultimate permanent adjustment. This reflects the fact that, when the target level of wealth rises, not only is a higher level of steady-state saving needed to maintain a higher target level of wealth, an immediate further boost to saving is necessary to move from the current (inadequate) level of wealth up to the new (higher) target. It means that an immediate jump in the saving rate is followed by a gradual decline toward a new equilibrium rate that is higher than the original one.

The above-mentioned studies are only some examples of influential papers in the subject. As the literature on precautionary saving is very rich, it deserved several review articles. The most recent reviews are those of Baiardi et al. (2020) and Lugilde et al. (2019). Baiardi et al. (2020) provide an overview of the latest developments in precautionary saving theory. They demonstrate that labour income risk is the main source of uncertainty in saving choice, and the starting point for the vast precautionary literature ignited with the seminal papers by Leland (1968), Sandmo (1970) and Dreze \& Modigliani (1972). Over time, the simple framework examined in early studies has become more complex. They review theory with interest rate uncertainty, high-order risk changes, uncertainty in non-financial variables, and other significant developments. Lugilde et al. (2019) provide a comprehensive review of the empirical literature discussing the main controversial issues and the different approaches followed by the studies addressing empirically the test of precautionary saving. They overview alternative dependent variables in the econometric exercises: the consumption level (or consumption growth), savings (level, growth, or the saving rate) or even wealth or its accumulation as well as different measures of the uncertainty: the income variability, the variability of GDP, the variability of consumption or expenditure, variables related to the labor market (mainly the unemployment rate). They emphasize that the question of how to measure uncertainty is still the most important unresolved issue.

Based on the above literature on precautionary saving, we formulate the hypothesis that increases in the financial wealth scaled to income and improvements in the credit availability decrease household saving propensity, while increments in perceived unemployment risk positively affect saving propensity. We test the hypothesis in un underexplored setting of particular interest. Most studies investigating household saving at the macroeconomic level focus on developed 
economies. Studies of former socialist economies in Central and Eastern Europe (CEE) are insufficient. Moving this field of research forwards is of great importance for the CEE countries, which have had at the same time both relatively low and fluctuating saving rates and also a volatile macroeconomic environment with large fluctuations in growth rates, unemployment and inflation rates (Kukk \& Staehr, 2017). However Poland's accession to the EU was associated with an increasing macroeconomic convergence in the aftermath of the accession, with few exceptions (convergence of business cycles). Liberda (2015) reveals that an improvement of the net international investment position of Poland requires the domestic saving rate to be raised, while the share of households savings in domestic savings demonstrates a declining trend. Kłopocka (2018b) provides more rationale for an increase in household saving in Poland. In this context the research on determinants of Polish household financial behavior is particularly relevant.

Some aspects of changes in Polish household saving behavior were discussed by, among others, Kłopocka (2017), Kolasa and Liberda (2015), Korzeniowska (2019), Kośny (2013), Kośny (2020), Potocki and Cierpiał-Wolan (2019), Swiecka et al. (2020). Still, household saving response to the uncertainty in Poland requires researchers' attention. This paper contributes to filling the gap in the literature by addressing the issue of household saving against unemployment risk in terms of changes in credit supply and households' financial wealth in Poland.

\section{Data and Method}

As mentioned earlier, empirical works on the analysis of precautionary savings differ in the dependent variable used, in the uncertainty measure and in the control variables included in the empirical analysis. In this paper, aimed at providing an empirical evaluation of the precautionary saving in Poland, we regress the gross household saving rate on the determinants implied by the model, in which saving depends on the gap between target and actual wealth, with the target determined by credit availability and unemployment expectations (Carroll et al., 2019). Therefore, we directly examine significance of the precautionary, wealth, and credit effects on the Polish household saving. We concentrate on the labor income uncertainty.
The gross household saving rate (SR) is calculated by dividing household gross saving by household gross disposable income, the latter being adjusted for the change in the net equity of households in pension funds reserves. The household saving rate published by Eurostat (ESA2010) is employed here.

In the literature on precautionary saving, labor income risk is the main source of uncertainty. We use unemployment expectation index (UE) as a proxy for the perceived risk of labor income loss. The index is based on survey data generated within the EU Programme of Business and Consumer Surveys. The question applied to construct the index is: 'How do you expect the number of people unemployed in this country to change over the next 12 months?' The index values range from -100 if all respondents choose the answer fall sharply (positive consumer sentiment, low unemployment risk) to +100 , if all respondents choose the option increase sharply (negative consumer sentiment, high unemployment risk). Detailed information on consumer survey methodology is presented in European Commission (2020).

To measure the credit supply conditions, the credit conditions index (CC) is constructed using the $\mathrm{Na}$ tional Bank of Poland's Senior Loan Officer Opinion Survey. The survey-participating banks evaluate seven factors of housing loans terms, as follows:

spread on average loans (wider spread - tightened, narrower margin - eased),

- $\quad$ spread on riskier loans,

- $\quad$ non-interest loan costs (fees, etc.) (higher costs tightened, lower costs - eased),

- security/collateral requirements,

maximum loan-to-value (LTV) ratio (lower

LTV ratio - tightened, higher ratio - eased),

maximum loan maturity (shorter -tightened, longer - eased), other terms.

Each factor is rated using the following scale:

- - tightened considerably

- tightened somewhat

$=$ remained basically unchanged

+ eased somewhat

++ eased considerably

N/A not applicable

The so-called net percentage is calculated for each factor, that is the difference between the percentage 


\section{Figure 1}

Gross Household Saving Rate, Unemployment Expectations Index and Credit Conditions Index

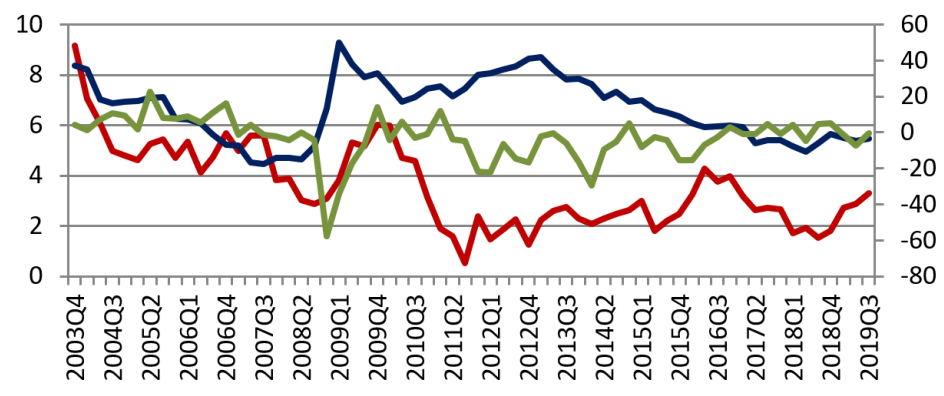

Gross Household Saving Rate (left axis)

Unemployment Expectations Index (right axis)

Credit Conditions Index*100 (right axis)

Note: Credit Condition Index is multiplied by 100 for the sake of series presentation.

of responses eased considerably and eased somewhat and the percentage of responses tightened considerably and tightened somewhat. A negative index indicates a tendency of tightening the terms of loans. The credit conditions index (CC) is the arithmetic average of the indexes calculated for each of the above mentioned seven factors of housing loans terms. Further information on the Senior Loan Officer Opinion Survey methodology is included in NBP (2019).

To capture the wealth channel, the ratio of household net financial assets to gross income (FW), published by Eurostat is used.

Moreover, the list of control variables include:

- the real gross household disposable income (IC) in billions (a thousand million) of national currency (PLN) (current values are deflated by the Harmonized Index of Consumer Prices (HICP)), published by Eurostat;

- the real 3-month interest rate (IR) (a representative short-term interest rate series for the domestic money market deflated by the HICP), published by Eurostat;
- the real GDP growth (GDP), published by the Central Statistical Office;

- the all-items Harmonized Index of Consumer Prices (HICP) (moving 12-months average rate of change), published by Eurostat; and

- the unemployment rate (UR) as a percentage of the active population, published by Eurostat.

The dataset covers quarterly observations from 2003 Q4 to 2019 Q3. The period under analysis is determined by the availability of data. Using quarterly data results in more data points and allows to take the dynamic structure of the data more seriously. Table 1 reveals the descriptive statistics of the variables. Appendix 1 provides plots of the series.

The key variables, namely, the gross household saving rate, the unemployment expectations index and the credit conditions index are visualized together in Figure 1. From the graph we can draw some preliminary conclusions about the dynamics of variables over the period of analysis.

There are some foundations to notice that the gross household saving rate reflects the path of unemploy- 
Table 1

Descriptive Statistics

\begin{tabular}{|c|c|c|c|c|c|c|}
\hline Variable & Symbol & Mean & Median & Min & Max & SD \\
\hline \multicolumn{7}{|l|}{ Levels } \\
\hline Gross Household Saving Rate (percentage) & SR & 3.56 & 3.12 & 0.53 & 9.16 & 1.64 \\
\hline Unemployment Expectations Index (points) & UE & 12.93 & 16.33 & -17.73 & 50.13 & 17.26 \\
\hline Credit Conditions Index (points) & $\mathrm{CC}$ & -0.03 & -0.01 & -0.58 & 0.23 & 0.12 \\
\hline Household Net Financial Assets to Gross Income Rate (percentage) & FW & 352.72 & 356.74 & 206.38 & 432.36 & 55.75 \\
\hline Real Gross Household Disposable Income (billion PLN) & IC & 234.5 & 238.8 & 153.8 & 333.8 & 521.9 \\
\hline Real Interest Rate (percentage) & IR & 1.70 & 1.69 & -0.39 & 4.90 & 1.16 \\
\hline Real GDP Growth (percentage) & GDP & 4.08 & 4.25 & 0.10 & 7.60 & 1.68 \\
\hline Harmonized Index of Consumer Prices (percentage) & HICP & 2.00 & 1.80 & -0.70 & 4.20 & 1.51 \\
\hline Unemployment Rate (percentage) & UR & 9.56 & 9.30 & 3.10 & 19.90 & 4.56 \\
\hline \multicolumn{7}{|l|}{ First differences } \\
\hline$\Delta$ Gross Household Saving Rate (percentage points) & $\Delta \mathrm{SR}$ & -0.09 & 0.07 & -2.09 & 1.84 & 0.79 \\
\hline$\Delta$ Unemployment Expectations Index (points) & $\Delta \mathrm{UE}$ & -0.55 & -0.52 & -16.50 & 37.00 & 7.32 \\
\hline$\Delta$ Credit Conditions Index (points) & $\Delta \mathrm{CC}$ & 0.00 & 0.00 & -0.53 & 0.23 & 0.12 \\
\hline $\begin{array}{l}\Delta \text { Household Net Financial Assets to Gross Income Rate } \\
\text { (percentage points) }\end{array}$ & $\Delta \mathrm{FW}$ & 1.54 & 3.13 & -63.54 & 47.87 & 17.31 \\
\hline$\Delta$ Real Gross Household Disposable Income (billion PLN) & $\Delta \mathrm{IC}$ & 2.85 & 2.87 & -3.13 & 14.43 & 2.48 \\
\hline$\Delta$ Real Interest Rate (percentage points) & $\Delta \mathrm{IR}$ & -0.08 & -0.03 & -1.61 & 0.78 & 0.36 \\
\hline$\Delta$ Real GDP Growth (percentage points) & $\Delta \mathrm{GDP}$ & -0.01 & 0.06 & -2.20 & 2.40 & 0.94 \\
\hline $\begin{array}{l}\Delta \text { Harmonized Index of Consumer Prices (percentage } \\
\text { points) }\end{array}$ & $\triangle \mathrm{HICP}$ & 0.02 & 0.00 & -0.80 & 1.00 & 0.42 \\
\hline$\Delta$ Unemployment Rate (percentage points) & $\Delta \mathrm{UR}$ & -0.26 & -0.30 & -1.60 & 1.20 & 0.50 \\
\hline
\end{tabular}

ment expectations index with some lag. Both variables share the downward slope until the turmoil of the Global Financial Crisis. Then the serious rise in perceived unemployment risk is pursued by an increase in the household saving rate. The peak of the unemployment expectations index (50 points) recorded in the first quarter of 2009 is followed by the local peak of the household saving rate (6 percent) three quarters later. After few quarters of the sharp decline in both variables (more profound and longer-lasting in case of the household saving rate) the lowest, close to zero level of household saving rate is noted. Later on, the mild intensification of unemployment risk is echoed in the increasing tendency in saving propensity, which persists even after 2012 in terms of the declining path of unemployment expectations index. The positive relationship of analyzed variables is visible again after 2015.
The household saving rate and credit conditions index relationship is less clear. The credit conditions index is relatively stable in the analyzed years apart from the period of 2008-2009. Taking into consideration theoretical underpinnings we may associate the sharp drop in credit conditions recorded in 2008Q4 with the high increase in household saving rate two quarters later. Similarly, the recovery in credit conditions is supposed to entail a substantial reduction in saving propensity with some lag. These observations suggest that changes in the credit conditions index have a negative effect on the household saving rate with some delay. The delay may be derived from the time required for the completion of credit procedures by credit applicants as well as for the transmission of bank managers decisions to public awareness. Our preliminary notes on bi- 
Table 2

ADFTest (p-values)

\begin{tabular}{|c|c|c|c|c|}
\hline \multirow[t]{2}{*}{ Variable } & \multicolumn{2}{|c|}{ Constant } & \multicolumn{2}{|c|}{ Constant and linear trend } \\
\hline & Level & First Difference & Level & First Difference \\
\hline Gross Household Saving Rate & 0.179 & $0.000^{* * *}$ & 0.297 & $0.000^{* * *}$ \\
\hline Unemployment Expectations Index & 0.142 & $0.000^{\star * *}$ & 0.402 & $0.000^{* * *}$ \\
\hline Credit Conditions Index & $0.001^{* * *}$ & $0.000^{\star * \star}$ & $0.005^{\star * *}$ & $0.000^{* * *}$ \\
\hline Household Net Financial Assets to Gross Income Rate & 0.557 & $0.000^{* * *}$ & 0.699 & $0.000^{* * *}$ \\
\hline Real Gross Household Disposable Income & 0.999 & $0.000^{* * *}$ & 0.692 & $0.000^{* * *}$ \\
\hline Real Interest Rate & 0.221 & $0.000^{* * *}$ & 0.233 & $0.001^{\star * *}$ \\
\hline Real GDP Growth & 0.131 & $0.000^{* * *}$ & 0.271 & $0.001^{* * *}$ \\
\hline Harmonized Index of Consumer Prices & 0.304 & $0.000^{* * *}$ & 0.537 & $0.002^{* * *}$ \\
\hline Unemployment Rate & 0.152 & $0.007^{* * *}$ & $0.053^{*}$ & $0.022^{\star *}$ \\
\hline
\end{tabular}

Note: ${ }^{* *},{ }^{* *},{ }^{\star}$ represent statistical significance at the $1 \%, 5 \%$, and $10 \%$ levels respectively.

variate relationships precede an in-depth econometric analysis in the multivariate context.

Considering the literature about spurious regressions with time-series data the Augmented DickeyFuller tests are performed. The tests are estimated both in levels and first differences, with and without a trend. Table 2 reports the results of the tests. Most variables are found to be integrated of order one or I(1) (the credit conditions index is the exception as it is $\mathrm{I}(0))$. I(1) variables should be differenced before they are used in linear regression models. It is the approach used in many times series regressions after Granger and Newbold's (1974) original paper on the spurious regression problem (Wooldridge, 2013). Therefore, all variables are first-differenced and changes in household saving rate are modelled as a function of changes in other economic variables.

We use quarterly data and allow for the possibility that the impact of explanatory variables on household saving is not purely contemporaneous but is also lagging to some extent. Hence, models with contemporaneous values and four lags (the typical number of lags in case of quarterly data) of independent variables are considered. The number of variables is to be limited to a necessary minimum given that a sample consists of only 59 observations (64 minus 1 due to first-differences, minus 4 due to lags) and models with only one value (contemporaneous or lagged) of each variable are preferred. The decision which value to use is made based on the evidence provided by the adjusted $\mathrm{R}^{2}$ and Akaike's Information Criterion (AIC) for alternative models. The baseline specification takes the following form:

$$
\begin{aligned}
& \Delta S R_{t}=\gamma_{0}+\gamma_{\Delta U E_{t-i}} \Delta U E_{t-i}+\gamma_{\Delta C C_{t-i}} \Delta C C_{t-i} \\
& +\gamma_{\Delta F W_{t-i}} \Delta F W_{t-i}+\varepsilon_{t}
\end{aligned}
$$

where $i=0,1, \ldots, 4, \mathrm{t}$ is a time subscript, UE symbolizes unemployment expectations index, CC stands for credit conditions index, FW represents household net financial assets to gross income rate, and $\varepsilon_{-} t$ is the error term.

We expect a positive correlation between saving and unemployment risk and a negative correlation with credit conditions and financial assets scaled to income.

In the second step of the analysis the baseline model is extended with control variables as follows:

$$
\begin{aligned}
& \Delta S R_{t}=\gamma_{0}+\gamma_{\Delta F W_{t-i}} \Delta F W_{t-i}+\gamma_{\Delta C C_{t-i}} \Delta C C_{t-i} \\
& +\gamma_{\Delta U E_{t-i}} \Delta U E_{t-i}+\gamma_{\Delta I C_{t-i}} \Delta I C_{t-i}+\gamma_{\Delta I R_{t-i}} \Delta I R_{t-i} \\
& +\gamma_{\Delta G D P g_{t-i}} \Delta G D P g_{t-i}+\gamma_{\Delta H I C P_{t-i}} \Delta H I C P_{t-i} \\
& +\gamma_{\Delta U R_{t-i}} \Delta U R_{t-i}+\varepsilon_{t}
\end{aligned}
$$

where IC represents income, IR - interest rate, GDPg - real GDP growth, HICP - inflation, and UR - unemployment rate. 


\section{Table 3}

Household Saving Rate Regressions

\begin{tabular}{|c|c|c|c|c|c|c|}
\hline Variable & (1) & (2) & (3) & (4) & (5) & (6) \\
\hline \multirow[t]{2}{*}{ Const } & 0.002 & $-0.474^{\star *}$ & 0.031 & -0.004 & -0.006 & -0.047 \\
\hline & $(0.074)$ & $(0.108)$ & $(0.079)$ & $(0.074)$ & $(0.072)$ & $(0.094)$ \\
\hline \multirow[t]{2}{*}{$\Delta$ Unemployment Expectations Index_3 } & $0.016^{*}$ & 0.009 & 0.012 & $0.015^{*}$ & 0.014 & $0.016^{* *}$ \\
\hline & $(0.008)$ & $(0.007)$ & $(0.009)$ & $(0.008)$ & $(0.009)$ & $(0.008)$ \\
\hline \multirow[t]{2}{*}{$\Delta$ Credit Conditions Index_2 } & $-2.673^{* * *}$ & $-1.984^{* * *}$ & $-2.446^{* * *}$ & $-2.821^{\star * *}$ & $-2.684^{* * *}$ & $-2.664^{* * *}$ \\
\hline & $(0.573)$ & $(0.415)$ & $(0.618)$ & $(0.661)$ & $(0.588)$ & $(0.572)$ \\
\hline$\Delta$ Net Financial Assets to Gross Income & $-0.012^{* * *}$ & $-0.010^{* * *}$ & $-0.014^{* * *}$ & $-0.011^{* * *}$ & $-0.013^{* * *}$ & $-0.012^{\star * *}$ \\
\hline Rate_4 & $(0.004)$ & $(0.003)$ & $(0.004)$ & $(0.003)$ & $(0.004)$ & $(0.004)$ \\
\hline \multirow[t]{2}{*}{$\Delta$ Real Disposable Income } & & $0.154^{* * *}$ & & & & \\
\hline & & $(0.024)$ & & & & \\
\hline \multirow[t]{2}{*}{$\Delta$ Real Interest Rate_ 4} & & & $0.354^{*}$ & & & \\
\hline & & & $(0.184)$ & & & \\
\hline \multirow[t]{2}{*}{$\Delta$ Real GDP Growth_3 } & & & & -0.098 & & \\
\hline & & & & $(0.080)$ & & \\
\hline \multirow[t]{2}{*}{$\triangle \mathrm{HICP}$} & & & & & $-0.303^{*}$ & \\
\hline & & & & & $(0.165)$ & \\
\hline \multirow[t]{2}{*}{$\Delta$ Unemployment Rate_4 } & & & & & & -0.186 \\
\hline & & & & & & $(0.184)$ \\
\hline $\mathrm{N}$ & 59 & 59 & 59 & 59 & 59 & 59 \\
\hline $\bar{R}^{2}$ & 0.301 & 0.528 & 0.316 & 0.302 & 0.312 & 0.305 \\
\hline F stat $\mathrm{p}$-value & 0.000 & 0.000 & 0.000 & 0.000 & 0.000 & 0.000 \\
\hline ADF test for residuals ( $\mathrm{p}$-values) & 0.000 & 0.000 & 0.000 & 0.000 & 0.000 & 0.000 \\
\hline
\end{tabular}

Notes: The table reports coefficients and their standard errors (in parentheses). Hypothesis tests were conducted using a heteroskedasticity and serial correlation robust covariance matrix. ${ }^{* *},{ }^{* *},{ }^{*}$ represent statistical significance at the $1 \%$, $5 \%$, and $10 \%$ levels respectively.

\section{Empirical Results and Discussion}

The following section presents and discusses empirical findings.

Table 3 reveals the results of Equation 1 and several variations on Equation 2. Column 1 of Table 3 provides the baseline model with three key independent variables according to Equation 1. Results demonstrate a statistically significant relationship between changes in household saving rate and lagged changes in unemployment risk, credit conditions and household financial assets scaled to income. Each independent variable is significant at least at the $10 \%$ level and jointly they explain $30 \%$ of the variation of the dependent variable (adjusted R2 equals 0.301). This is a relatively good result for the model on first differences. The results of
$\mathrm{ADF}$ test for residuals are presented. A fact that the residual time series is stationary is a further indication of the good quality of the model. Thus, we receive a model with good stochastic values in which all explanatory variables are stationary and residuals from the model are stationary. As expected, there is a strong positive correlation of changes in household saving rate with lagged changes in unemployment expectations index, and a strong negative correlation with lagged changes in credit conditions index and lagged changes in financial assets to income ratio.

It can be interpreted that an increase by 1 percentage point in the difference of unemployment expectations index results in an increase in the difference of household saving rate by 0.016 percentage point 


\section{Table 4}

Household Saving Rate Regressions

\begin{tabular}{|c|c|c|}
\hline Variable & (1) & (2) \\
\hline \multirow[t]{2}{*}{ Const } & -0.040 & $-0.463^{* * *}$ \\
\hline & $(0.106)$ & $(0.109)$ \\
\hline \multirow[t]{2}{*}{$\Delta$ Unemployment Expectations Index_3 } & 0.007 & 0.002 \\
\hline & $(0.009)$ & $(0.009)$ \\
\hline \multirow[t]{2}{*}{$\Delta$ Credit Conditions Index _2 } & $(0.009)$ & $(0.009)$ \\
\hline & $-2.461^{\star * *}$ & $-1.817^{\star * *}$ \\
\hline \multirow[t]{2}{*}{$\Delta$ Net Financial Assets to Gross Income Rate_ 4} & $(0.686)$ & $(0.498)$ \\
\hline & $-0.017^{\star * *}$ & $-0.015^{\star * *}$ \\
\hline \multirow[t]{2}{*}{$\Delta$ Real Disposable Income } & & $0.143^{* * *}$ \\
\hline & & $(0.000)$ \\
\hline \multirow[t]{2}{*}{$\Delta$ Real Interest Rate_4 } & $0.452^{\star *}$ & $0.399^{* *}$ \\
\hline & $(0.183)$ & $(0.168)$ \\
\hline \multirow[t]{2}{*}{$\Delta$ Real GDP Growth_3 } & -0.046 & -0.019 \\
\hline & $(0.084)$ & $(0.079)$ \\
\hline \multirow[t]{2}{*}{$\triangle \mathrm{HICP}$} & $-0.524^{* * *}$ & $-0.440^{* * *}$ \\
\hline & $(0.181)$ & $(0.159)$ \\
\hline \multirow[t]{2}{*}{$\Delta$ Unemployment Rate_4 } & -0.236 & -0.162 \\
\hline & $(0.193)$ & $(0.189)$ \\
\hline $\mathrm{N}$ & 59 & 59 \\
\hline$R^{2}$ & 0.359 & 0.564 \\
\hline F stat p-value & 0.000 & 0.000 \\
\hline ADF test for residuals ( $p$-values) & 0.000 & 0.000 \\
\hline
\end{tabular}

Notes: The table reports coefficients and their standard errors (in parentheses). Hypothesis tests were conducted using a heteroskedasticity and serial correlation robust covariance matrix. ${ }^{* *},{ }^{* *},{ }^{*}$ represent statistical significance at the $1 \%$, $5 \%$, and $10 \%$ levels respectively.

three quarters later, all other factors being equal. An increase by 1 percentage point in the difference of credit conditions index results in a decrease in the difference of household saving rate by 2.67 percentage point two quarters later, all other factors being equal. The analogous interpretation is applicable for the coefficient of changes in financial assets to income ratio. The results demonstrate a statistically significant and economically important role of all three explanatory variables.

Figure 2 reveals a static one-step ahead forecast of household saving rate (levels), generated for the baseline model, based on realized values from the previous period. It visualizes that the model is able to capture well the observed change in the saving rate.
To diagnose the stability of the model over time we perform Cumulated Sum of Residuals (CUSUM) and Cumulated Sum of Square Residuals (CUSUMSQ) tests (see Figure 3). The procedure is that under the null hypothesis of coefficient constancy, values of the sequence outside an expected range suggest structural change in the model over time. The condition of stability is achieved when both CUSUM and CUSUMSQ lines fall within the $5 \%$ significant level. Our plots indicate that neither test rejects the null hypothesis that coefficients are stable. This suggests that model is stable over time.

Columns 2-6 of Table 3 present a set of specifications of the baseline model extended with other potential determinants of saving, according to Equation 2, with re- 


\section{Figure 2}

Actual and forecasted Household Saving Rate upon the baseline model

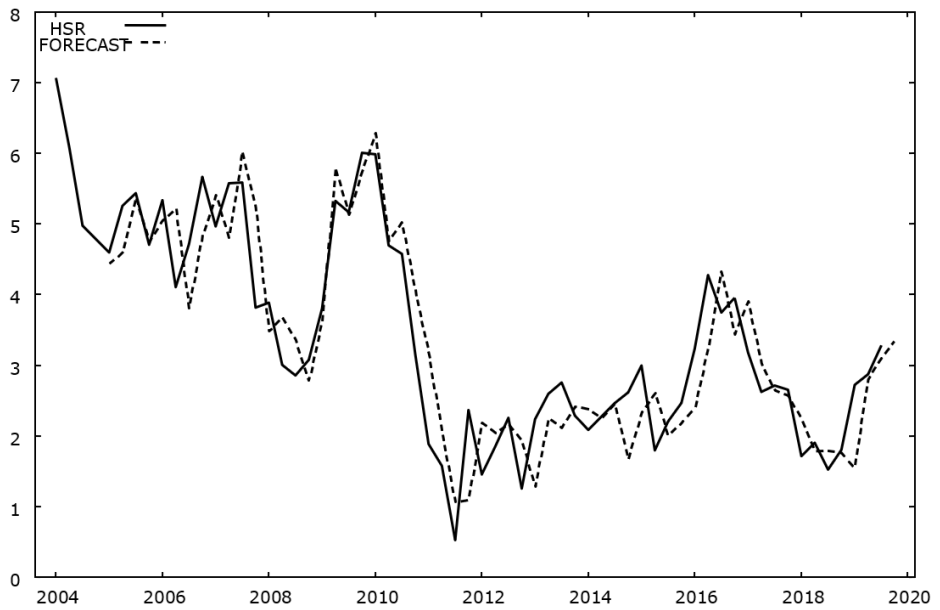

strictions. The procedure was to add a contemporaneous value or one of four lags of a given control variable to the baseline model one by one. We report here models with the best fit for each control variable chosen based on adjusted R2 and AIC measures. To be strict, in the model of:

- Column 2 - coefficients of all control variables apart from first difference in income (contemporaneous) equal to zero

- Column 3 - coefficients of all control variables apart from first difference in real interest rate (lag 4 ) equal to zero

- Column 4 - coefficients of all control variables apart from first difference in real GDP growth (lag 3 ) equal to zero

- Column 5 - coefficients of all control variables apart from first difference in inflation (contemporaneous) equal to zero

- Column 6 - coefficients of all control variables apart from first difference in unemployment rate (lag 4) equal to zero.

In all specifications, the coefficients on credit conditions index and net financial assets to income ratio hold their statistical significance at the $1 \%$ level. As far as the unemployment expectations index is regarded, adding changes in income, real interest rate, and inflation kills its statistical significance (Columns 2, 3, 5, respectively). Still, the estimated coefficients on the three key variables remain broadly unchanged compared with the baseline specification in all but one model. The exception is the model with contemporaneous change in income (Column 2) which offers the greatest improvement in the model fit (adjusted R2 increased to approximately 0.53 ). This is not surprising given the fact that fundamental theoretical considerations on consumption and saving (including Keynesian hypothesis, the permanent income hypothesis, the Ricardian equivalence hypothesis, the relative-income hypothesis) put income (current/permanent/relative) in the center of attention. The role of income in saving decisions is also confirmed by numerous empirical studies (Cerda et al., 2020; Grigoli et al., 2018; Szopinski, 2019). As expected, we find positive relationship of changes in household saving rate with changes in income.

According to the theoretical underpinnings, the link between saving rate and interest rate is a result of the substitution effect and the income ef- 


\section{Figure 3}

(a) Cumulated Sum of Residuals (CUSUM) and (b) Cumulated Sum of Square Residuals (CUSUMSQ)

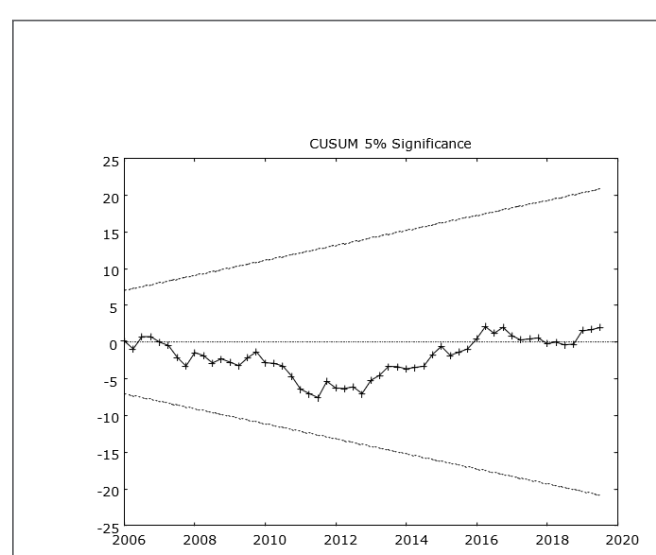

(a)

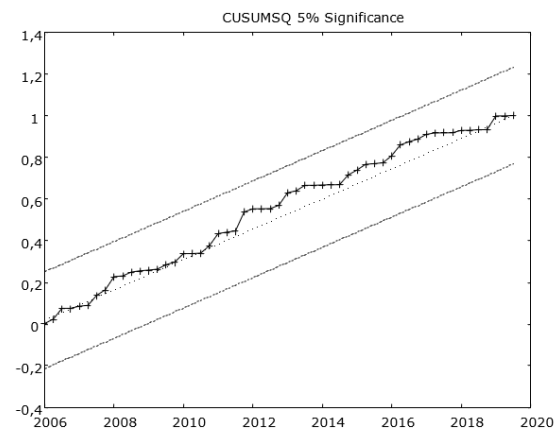

(b) fect which go in opposite directions, hence the combined net effect is ambiguous. Opoku (2020) provides evidence that the net effect differs in the short run and long run. In our study the statistically significant positive effect of the lagged difference in interest rate on the difference in household saving rate documented in Column 3 of Table 3 may support the dominance of substitution effect.

The consumption/saving literature recognizes the multi-channel influence of inflation on household saving rate (Grigoli et al., 2018). The negative sign of the coefficient for the difference in HICP (Column 5 Table 3) focuses our attention on the fact that higher inflation lowers real interest rate. Given the abovementioned dominance of interest rate substitution effect, higher inflation reduces the saving rate.

Interestingly, the specification in Column 6 of Table 3 reveals that first difference in the unemployment rate does not turn out to be statistically significant while the level of significance of lagged difference in unemployment expectations index improves. Bande and Riveiro (2013), Bouyon (2016) reveal results that the unemployment rate is a relevant variable as a measure of future income uncertainty. We provide an empirical support for the claim that perceived unemployment risk is a better proxy of labor income risk than the unemployment rate. Similar finding for the US household saving behavior is provided by Carroll et al. (2012). Kłopocka (2017) reveals that some consumer confidence indexes (subjective indicators), in particular the unemployment expectations index, contain predictive ability for Polish household saving and borrowing rates beyond economic fundamentals (objective indicators). These results are also consistent with evidence put forth by Broadway \& HaiskenDeNew (2019) from Australian households. They exhibit that perceived income uncertainty increases precautionary savings above and beyond the effect of real income uncertainty. Therefore, we contribute to the discussion on the choice of uncertainty measures referring to the labor market with a recommendation to employ the subjective (perceived) unemployment expectation index rather than the objective unemployment rate.

Table 4 reports household saving rate models including most (Column 1) or all control variables (Column 2) at the same time. It supports our findings based on econometric results presented in Table 3. 
The evidence of lagged response in household saving rate to changes in unemployment expectations index set our results in the context of consumer sentiment and household consumption expenditures relationship. Our findings are in line with studies confirming the forecasting ability of consumer sentiment (including unemployment expectations) for household expenditure (e.g. Bram \& Ludvigson, 1998; Bruestle \& Crain, 2015; Carroll et al., 1994; Dees \& Brinca, 2013; Ludvigson, 2004).

The COVID-induced massive increase of uncertainty level calls for further exploration of the uncertainty impact on household propensity to save. The range of uncertainty measures going beyond labor income risk is broad and developing (Altig et al., 2020; Baker et al., 2016; Claveria et al., 2019; Malovaná et al., 2021; Wang et al., 2019). Although employing these indicators is clearly out of the scope of this paper, it is a very interesting research path left for future investigation.

This analysis is restricted to the macroeconomic level. In case of aggregated data, only a net result of processes is visible (some processes occurring in a subgroup of units can be counteracted in another subgroup). Aizenman et al. (2015) highlight the complexity and difficulty to capture the interaction between saving behavior and uncertainty at the aggregate level. This is an incentive to re-examine the problem with the household level data to obtain an in-depth picture, in particular, to account for differences in the precautionary saving motive relevance for different age groups as suggested by Cagetti (2003) and Chamon et al. (2013).

This study is limited to Poland - one of the CEE countries. This is a region with unique post-communist history still not sufficiently covered with advanced economic studies on household saving behavior. Household-sector balance sheets (including financial assets and liabilities) reflect financial inclusiveness and financial development of a country and thus impact economic growth (Nizam et al., 2020; Škare et al., 2019). Household saving behavior is of interest in and of itself. However, its relationships with economic growth and business cycles (Białowąs \& Olejnik, 2015) make the issue deserve in-depth studies even more, especially in a region which aspire to catch up on richer EU members.

\section{Conclusions}

In general, the baseline household saving model presented in the paper accounts for a substantial part in household saving rate changes. Our empirical findings strongly support the important role of financial wealth and credit effects on Polish households' saving propensity. Consistent with the buffer-stock model, increases in the financial wealth scaled to income and improvements in the credit availability decrease household saving propensity, while increments in perceived unemployment risk positively affect changes in saving rate. Our baseline model estimates support the claim that Polish households buffer-save against labor income loss. When control variables are added to the equation, wealth and credit supply variables remain statistically significant at a level higher than $1 \%$. Furthermore, this paper contributes to the discussion on the choice of uncertainty measures referring to the labor market with a recommendation to employ the subjective (perceived) unemployment expectation index rather than the objective unemployment rate.

These results are meaningful in terms of policy implications. They emphasize the role of credit availability for household consumption/saving decisions. In case of expansionary monetary policy and making credit easier to acquire for households, all other things equal, a negative effect on the household saving rate may be expected. This poses a question about the risk of households' overreliance on credit and therefore about their financial stability in emergency situations. Given COVID-induced increasingly loose credit policy of central banks accompanied by augmented economic uncertainty, household-sector balance sheet calls for particular attention of policymakers, banking supervisory authorities, and financial institutions. There is a need for educational measures aimed at increasing households' financial capability, developing future orientation, and highlighting the role of self-regulation.

These results provide a number of possibilities for further research. First, other uncertainty measures going beyond the labor income risk could be included in the analysis. The role of fiscal policy (in the context of - much debated - Ricardian equivalence) and its interactions with monetary policy could be also considered. Direct monetary effects on household 
savings can be transmitted through credit conditions while fiscal effects through income and unemployment risk variables. Opposite to monetary policy, fiscal policy can be more diversified, for example, with regard to the level of income of households upon which their saving decisions depend. Consequently, analyses at the microeconomic level are strongly recommended. Moreover, future researches could ensure access to panel data for CEE countries to capture the unemployment risk, wealth and credit effects on household saving in the broader perspective.

\section{Acknowledgements}

This paper was presented at the international conference "Challenges of Contemporary Economics" (September, 13-15, 2020) organized by the University of Economics and Human Sciences in Warsaw, Poland.

\section{References}

Aizenman, J., Cavallo, E., \& Noy, I. (2015). Precautionary strategies and household saving. Open Economies Review, 26(5), 911-939. https:// doi.org/10.1007/s11079-015-9351-2

Altig, D., Baker, S., Barrero, J. M., Bloom, N., Bunn, P., Chen, S., Davis, S. J., Leather, J., Meyer, B., \& Mihaylov, E. (2020). Economic uncertainty before and during the COVID-19 pandemic. Journal of Public Economics, 191, 1-26. https://doi. org/10.1016/j.jpubeco.2020.104274

Baiardi, D., Magnani, M., \& Menegatti, M. (2020). The theory of precautionary saving: An overview of recent developments. Review of Economics of the Household, 18(2), 513-542. https://doi. org/10.1007/s11150-019-09460-3

Baker, S. R., Bloom, N., \& Davis, S. J. (2016). Measuring economic policy uncertainty. The Quarterly Journal of Economics, 131(4), 1593-1636. https:// doi.org/10.1093/qje/qjw024

Bande, R., \& Riveiro, D. (2013). Private saving rates and macroeconomic uncertainty: Evidence from Spanish regional data. Economic and Social Review, 44(3), 323-349. https://www.esr.ie/ article/view/75

Bertaut, C. C., \& Haliassos, M. (1997). Precautionary portfolio behavior from a life-cycle perspective. Journal of Economic Dynamics and Control, 21(8), 1511-1542. https://doi.org/10.1016/S01651889(97)00060-2

Białowąs, S., \& Olejnik, I. (2015). Oszczędności gospodarstw domowych w różnych fazach cyklu koniunkturalnego [Household savings in different phases of the business cycle]. Studia Oeconomica Posnaniensia, 3(4), 153-165.

Bouyon, S. (2016). Policy options for european household saving. Journal of Economic Integration, 31(1), 134-165. https://doi.org/10.11130/ jei.2016.31.1.134

Bram, J., \& Ludvigson, S. C. (1998). Does consumer confidence forecast household expenditure? A Sentiment Index Horse Race. FRBNY Economic Policy Review, 4(2), 59-78.

Broadway, B., \& Haisken-DeNew, J. P. (2019). Keep calm and consume? Subjective uncertainty and precautionary savings. Journal of Economics and Finance, 43(3), 481-505. https://doi.org/10.1007/ s12197-018-9451-0

Bruestle, S., \& Crain, W. M. (2015). A mean-variance approach to forecasting with the consumer confidence index. Applied Economics, 47(23), 2430-2444. https://doi.org/10.1080/00036846.20 15.1008763

Cagetti, M. (2003). Wealth accumulation over the life cycle and precautionary savings. Journal of Business \& Economic Statistics, 21(3), 339-353. https://doi.org/10.1198/073500103288619007

Carroll, C. D. (1992). The buffer-stock theory of saving: Some macroeconomic evidence. Brookings Papers on Economic Activity, 1992(2), 61-135. https://doi. org/10.2307/2534582

Carroll, C. D. (1997). Buffer-stock saving and the life cycle/permanent income hypothesis. The Quarterly Journal of Economics, 112(1), 1-55. https://doi.org/10.1162/003355397555109

Carroll, C. D., \& Samwick, A. A. (1997). The nature of precautionary wealth. Journal of Monetary Economics, 40(1), 41-71. https://doi.org/10.1016/ S0304-3932(97)00036-6

Carroll, C. D., Slacalek, J., \& Sommer, M. (2012). Dissecting saving dynamics: Measuring wealth, precautionary and credit effects. ECB Working Paper Series No 1474, 1-50.

Carroll, C. D., Slacalek, J., \& Sommer, M. (2019). Dissecting saving dynamics: Measuring wealth, precautionary, and credit effects. NBER Working Paper Series, 26131. https://www.nber.org/papers/ w26131

Carroll, C., Fuhrer, J., \& Wilcox, D. (1994). Does consumer sentiment forecast household spending -if so, why. American Economic Review, 84(5), 1397-1408.

Cerda, R., Fuentes, R., García, G., \& Llodrá, J. I. (2020). Understanding domestic savings: An empirical approach. Applied Economics, 52(9), 905-928. https://doi.org/10.1080/00036846.2019.1646871

Ceritoğlu, E. (2013). The impact of labour income risk on household saving decisions in Turkey. Review of Economics of the Household, 11(1), 109-129. https://doi.org/10.1007/s11150-011-9137-2

Chamon, M., Liu, K., \& Prasad, E. (2013). Income uncertainty and household savings in China. Journal of Development Economics, 105 (C), 164- 
177. https://doi.org/10.1016/j.jdeveco.2013.07.014 Claveria, O., Monte, E., \& Torra, S. (2019). Empirical modelling of survey-based expectations for the design of economic indicators in five European regions. Empirica, 46(2), 205-227. https://doi. org/10.1007/s10663-017-9395-1

Czerwonka, M. (2019). Cultural, cognitive and personality traits in risk-taking behaviour: Evidence from Poland and the United States of America. Economic Research-Ekonomska Istraživanja, 32(1), 894-908. https://doi.org/10.10 80/1331677X.2019.1588766

Deaton, A. (1991). Saving and liquidity constraints. Econometrica, 59(5), 1221-1248. https://doi. org $/ 10.2307 / 2938366$

Dees, S., \& Brinca, P. S. (2013). Consumer confidence as a predictor of consumption spending: Evidence for the United States and the Euro area. International Economics, 134, 1-14. https://doi. org/10.1016/j.inteco.2013.05.001

Deidda, M. (2014). Precautionary saving under liquidity constraints: Evidence from Italy. Empirical Economics, 46(1), 329-360. https://doi. org/10.1007/s00181-012-0677-y

Dreze, J. H., \& Modigliani, F. (1972). Consumption decisions under uncertainty. Journal of Economic Theory, 5(3), 308-335. https://doi.org/10.1016/ B978-0-12-780850-5.50041-1

Dynan, K. (1993). How prudent are consumers. Journal of Political Economy, 101(6), 1104-1113. https://doi.org/10.1086/261916

European Commission. (2020). The joint harmonised EU programme of business and consumer surveys. user guide. European Commission. https:// ec.europa.eu/info/sites/info/files/bcs_user_ guide_2020_02_en.pdf

Fereidouni, H. G., \& Tajaddini, R. (2017). Housing wealth, financial wealth and consumption expenditure: The role of consumer confidence. Journal of Real Estate Finance and Economics, 54(2), 216-236. https://doi.org/10.1007/s11146015-9537-9

Fulford, S. L. (2015). The surprisingly low importance of income uncertainty for precaution. European Economic Review, 79, 151-171. https://doi. org/10.1016/j.euroecorev.2015.07.016

Gomes, F. J., Haliassos, M., \& Ramadoral, T. (2021). Household finance. Journal of Economic Literature, 59(3), 919-1000.

Granger, C. W., \& Newbold, P. (1974). Spurious regressions in econometrics. Journal of Econometrics, 2(2), 111-120.

Grigoli, F., Herman, A., \& Schmidt-Hebbel, K. (2018). Saving in the world. World Development, 104, 257-270. https://doi.org/10.1016/j. worlddev.2017.11.022

Gunning, J. W. (2010). Risk and savings: A taxonomy. Economics Letters, 107(1), 39-41. https://doi. org/10.1016/j.econlet.2009.12.020

Harasim, J. (2012). Financial decision-making under uncertainty-cross-cultural differences. Studia Ekonomiczne / Uniwersytet Ekonomiczny $w$ Katowicach, nr 106 Finanse $w$ niestabilnym otoczeniu-dylematy i wyzwania : rynki finansowe, 225-233.

Hubbard, R. G., Skinner, J., \& Zeldes, S. P. (1994). The importance of precautionary motives in explaining individual and aggregate saving. Carnegie-Rochester Conference Series on Public Policy, 40, 59-125. https://doi.org/10.1016/01672231(94)90004-3

Kłopocka, A. M. (2017). Does Consumer Confidence Forecast Household Saving and Borrowing Behavior? Evidence for Poland. Social Indicators Research, 133(2), 693-717. https://doi. org/10.1007/s11205-016-1376-4

Kłopocka, A. M. (2018a). Does the buffer stock model explain the household saving rate in Poland? In F. Chybalski \& M. Marcinkowska (Eds.), Contemporary problems of intergenerational relations and pension systems: A theoretical and empirical perspective (pp. 174-183). Lodz University of Technology Press.

Kłopocka, A. M. (2018b). Skłonność gospodarstw domowych do oszczędzania a wiedza finansowa [Household propensity to save and financial knowledge]. Bank i Kredyt, 49(5), 461-492.

Kolasa, A., \& Liberda, B. (2015). Determinants of saving in Poland: Are they different from those in other OECD countries? Eastern European Economics, 53(2), 124-148. https://doi.org/10.108 0/00128775.2015.1033276

Korzeniowska, A. M. (2019). Institutional determinants of household savings in Poland. Journal of Research in Business, 1(4), 55-63. https://doi.org/10.23892/JRB.2019453295

Kośny, M. (2013). Economic activity, saving, credit and income polarisation in Poland. Post-Communist Economies, 25(4), 512-528. https://doi.org/10.108 $0 / 14631377.2013 .844931$

Kośny, M. (2020). Economic resourcefulness as a determinant of saving and borrowing in Poland. Post-Communist Economies, 32(6), 793-812. https://doi.org/10.1080/14631377.2020.1727264

Kukk, M., \& Staehr, K. (2017). Macroeconomic factors in the dynamics of corporate and household saving: Evidence from Central and Eastern Europe. Emerging Markets Finance and Trade, 53(11), 2585-2608. https://doi.org/10.1080/1540 496X.2016.1262759

Lee, J.-J., \& Sawada, Y. (2007). The degree of precautionary saving: A reexamination. Economics Letters, 96(2), 196-201.

Leland, H. E. (1968). Saving and uncertainty: The precautionary demand for saving. The Quarterly Journal of Economics, 82(3), 465. https://doi. org $/ 10.2307 / 1879518$

Liberda, B. (2015). Macroeconomic savings in Poland. Ekonomista, 4, 437-451.

Limosani, M., \& Millemaci, E. (2014). Precautionary 
savings of agents with heterogeneous risk aversion. Applied Economics, 46(20), 2342-2361. https://doi.org/10.1080/00036846.2014.896983

Ludvigson, S. C. (2004). Consumer confidence and consumer spending. Journal of Economic Perspectives, 18(2), 29-50. https://doi. org/10.1257/0895330041371222

Lugilde, A., Bande, R., \& Riveiro, D. (2019). Precautionary saving: A review of the empirical literature. Journal of Economic Surveys, 33(2), 481-515. https://doi.org/10.1111/joes.12284

Lusardi, A. (1998). On the importance of the precautionary saving motive. American Economic Review, 88(2), 449-453.

Malovaná, S., Hodula, M., \& Frait, J. (2021). What does really drive consumer confidence? Social Indicators Research. https://doi.org/10.1007/ s11205-021-02626-6

Mastrogiacomo, M., \& Alessie, R. (2014). The precautionary savings motive and household savings. Oxford Economic Papers-New Series, 66(1), 164-187. https://doi.org/10.1093/oep/ gpt028

Mishra, A. K., Uematsu, H., \& Powell, R. R. (2012). Precautionary wealth and income uncertainty: A household-level analysis. Journal of Applied Economics, 15(2), 353-369. Scopus. https://doi. org/10.1016/S1514-0326(12)60015-4

Mody, A., Ohnsorge, F., \& Sandri, D. (2012). Precautionary savings in the Great Recession. IMF Economic Review, 60(1), 114-138.

NBP. (2019). Senior loan officer opinion survey on bank lending practices and credit conditions (4th quarter 2019). NBP.

Nizam, R., Karim, Z. A., Rahman, A. A., \& Sarmidi, T. (2020). Financial inclusiveness and economic growth: New evidence using a threshold regression analysis. Economic Research-Ekonomska Istraživanja, 33(1), 1465-1484. https://doi.org/10 $.1080 / 1331677$ X.2020.1748508

Odoardi, I., \& Pagliari, C. (2020). Household wealth as a factor of economic growth: A Case Study of Italy. Contemporary Economics, 14(3), 337-353. https:// doi.org/10.5709/ce.1897-9254.408

Opoku, P. K. (2020). The short-run and long-run determinants of household saving: Evidence from OECD economies. Comparative Economic Studies, 62(3), 430-464.

Potocki, T., \& Cierpiał-Wolan, M. (2019). Factors shaping the financial capability of low-income consumers from rural regions of Poland. International Journal of Consumer Studies, 43(2), 187-198. https://doi. org/10.1111/ijcs.12498

Rybaczewska, M., Sparks, L., \& Sułkowski, Ł. (2020). Consumers' purchase decisions and employer image. Journal of Retailing and Consumer Services, 55, 102123.

Sandmo, A. (1970). The effect of uncertainty on saving decisions. The Review of Economic Studies, 37(3), 353-360.
Simon, H. A. (1955). A behavioral model of rational choice. The Quarterly Journal of Economics, 69(1), 99-118.

Škare, M., Sinković, D., \& Porada-Rochoń, M. (2019). Financial development and economic growth in Poland 1990-2018. Technological and Economic Development of Economy, 25(2), 103-133.

Skinner, J. (1988). Risky income, life-cycle consumption, and precautionary savings. Journal of Monetary Economics, 22(2), 237-255. https:// doi.org/10.1016/0304-3932(88)90021-9

Swiecka, B., Yeşildağ, E., Özen, E., \& Grima, S. (2020). Financial literacy: The case of Poland. Sustainability, 12(2), 700. https://doi.org/10.3390/ su12020700

Szopinski, T. (2019). Who is unbanked? Evidence from Poland. Contemporary Economics, 13(4), 417-427.

Thimme, J. (2016). Intertemporal substitution in consumption: A literature review. Journal of Economic Surveys, 31(1), 226-257. https://doi. org/10.1111/joes.12142

Vinokurov, S. S., Medved, A. A., \& Mierin, L. A. (2018). Economic news and household decisions. Contemporary Economics, 12(1), 57-68.

Wang, P., Li, X., Zhan, X., Zhang, Y., Yan, Y., \& Meng, W. (2019). Building consumer confidence index based on social media big data. Human Behavior and Emerging Technologies, 1(3), 261-268. https:// doi.org/10.1002/hbe2.156

Wooldridge, J. M. (2013). Introductory econometrics: A modern approach (5th ed). South-Western Cengage Learning. 
Appendix 1. Variables, levels and first differences

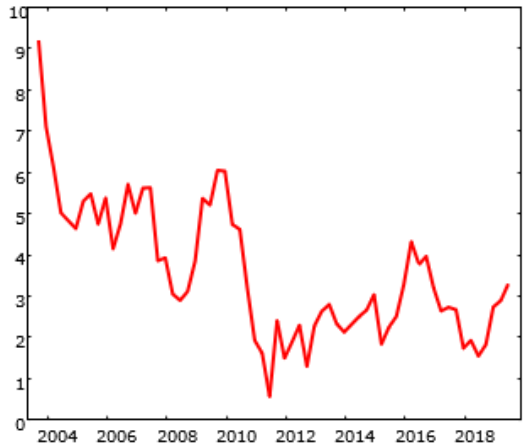

(a) Gross Household Saving Rate (percentage)

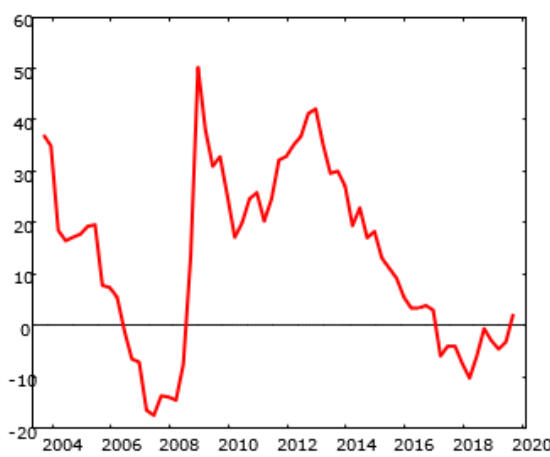

(c) Unemployment Expectations Index (points)

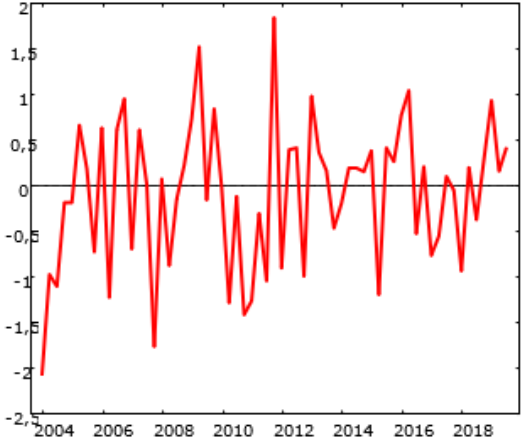

(b) $\Delta$ Gross Household Saving Rate (percentage points)

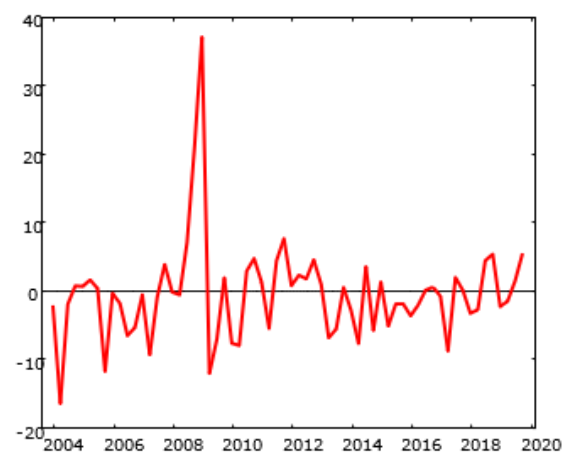

(d) $\Delta$ Unemployment Expectations Index (points)

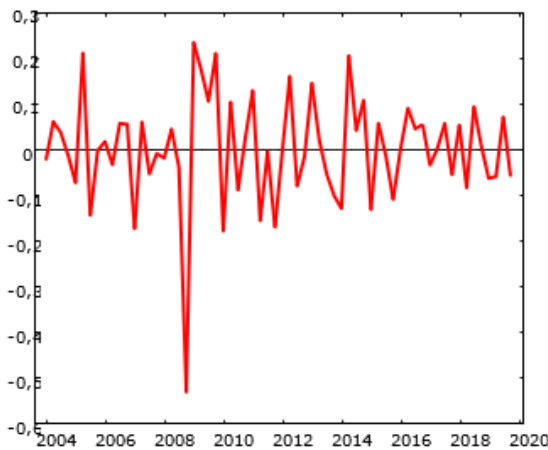

(f) $\Delta$ Credit Conditions Index (points)

(e) Credit Conditions Index (points) 


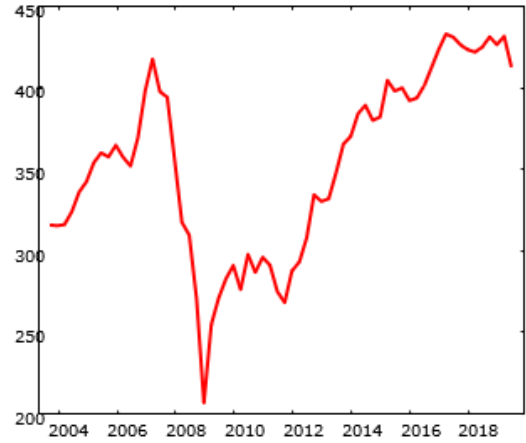

(g) Household Net Financial Assets to Gross Income Rate (percentage)

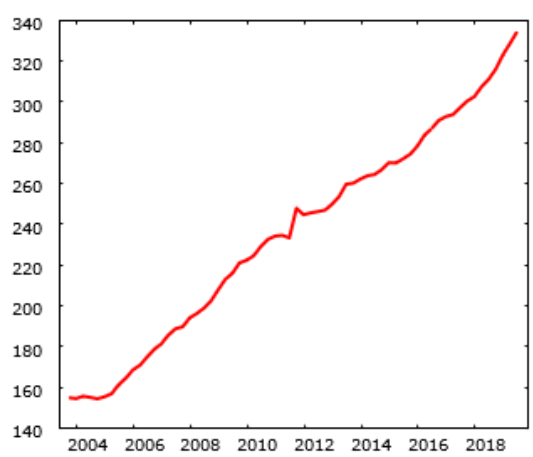

(i) Real Gross Household Disposable Income (billion PLN)

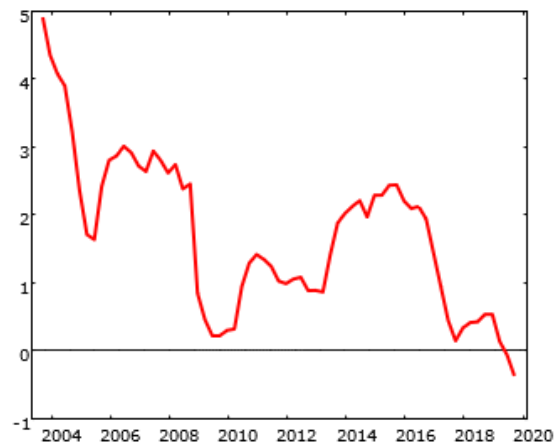

(k) Real Interest Rate (percentage)

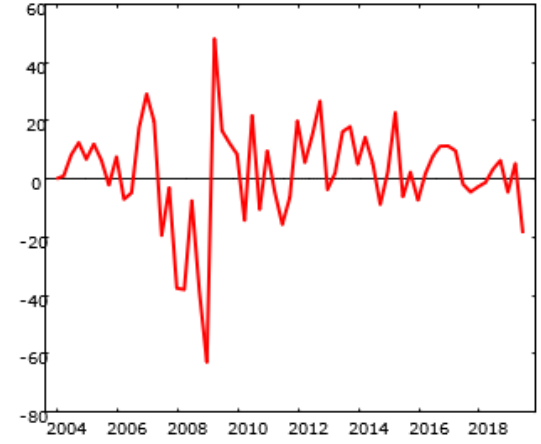

(h) $\Delta$ Household Net Financial Assets to Gross Income Rate (percentage points)

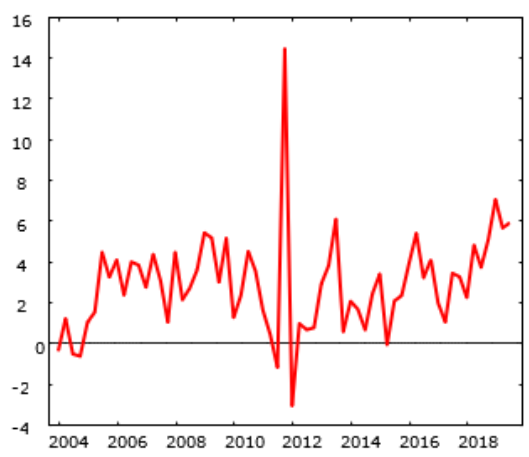

(j) $\Delta$ Real Gross Household Disposable Income (billion PLN)

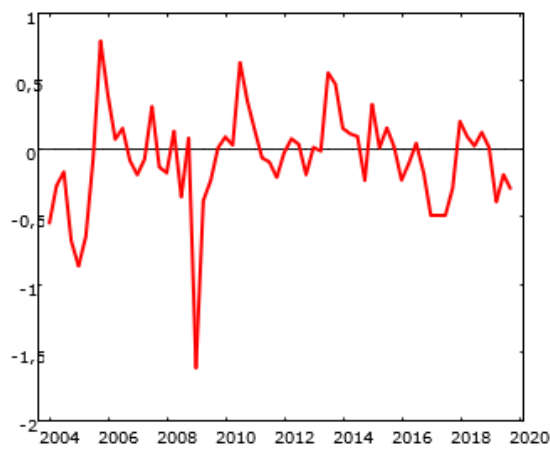

(l) $\Delta$ Real Interest Rate (percentage points) 


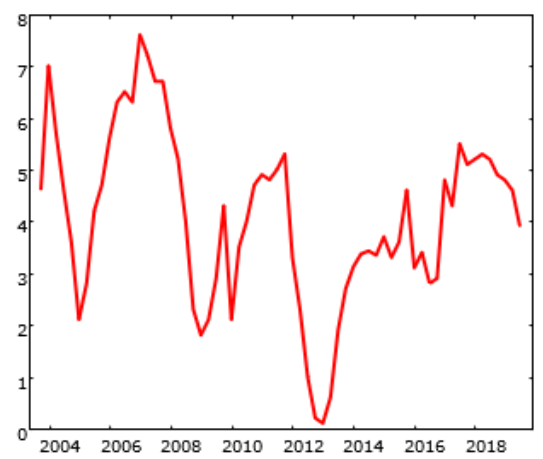

(m) Real GDP Growth (percentage)

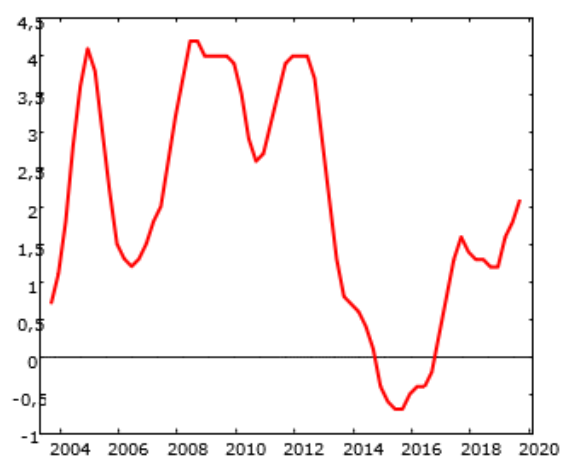

(o) Harmonized Index of Consumer Prices (percentage)

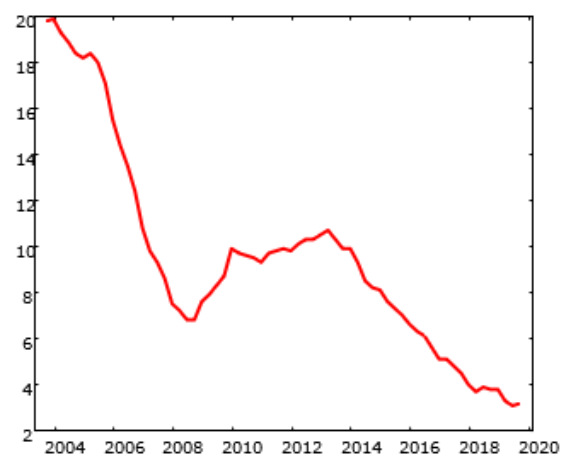

(r) Unemployment Rate (percentage)

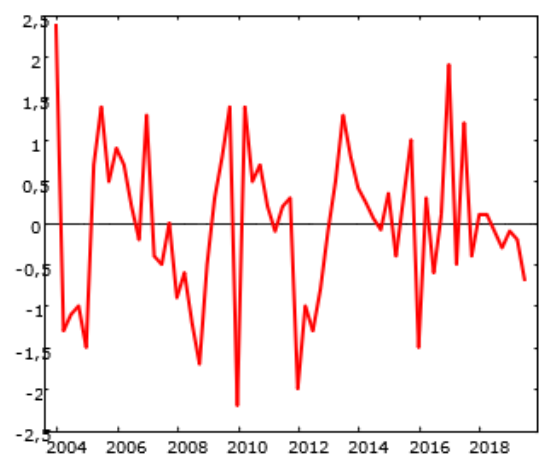

(n) $\Delta$ Real GDP Growth (percentage points)

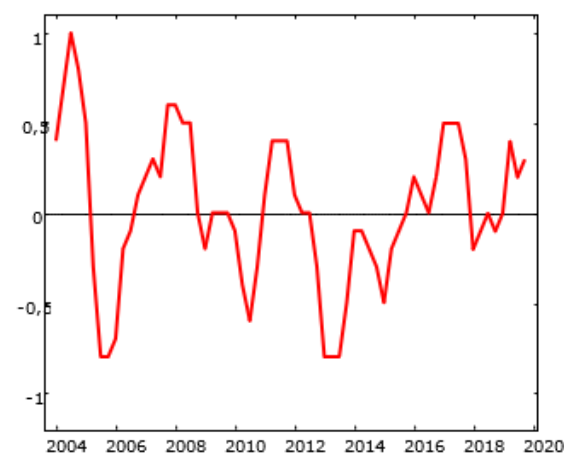

(p) $\Delta$ Harmonized Index of Consumes Prices (percentage points)

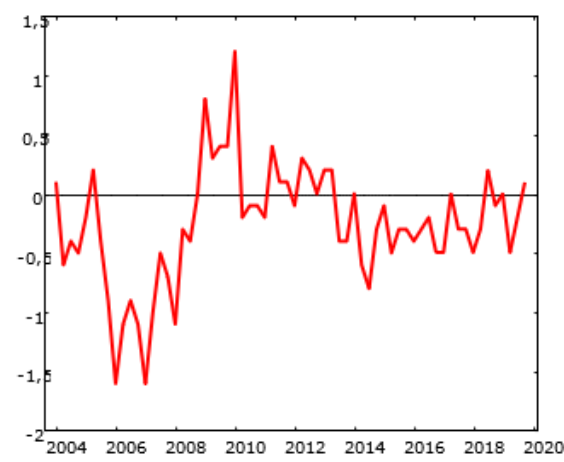

(s) $\Delta$ Unemployment Rate (percentage points) 